\title{
Adoption of digital marketing among farm tourism sites in the province of Quezon, Philippines
}

\author{
Orias, Mary Joyce S. $\triangle$ \\ Lyceum of the Philippines University Batangas, Philippines (mjoyce.orias@gmail.com) \\ Borbon, Noelah Mae D. \\ Lyceum of the Philippines University Batangas, Philippines (nmdborbon@lpubatangas.edu.ph)
}

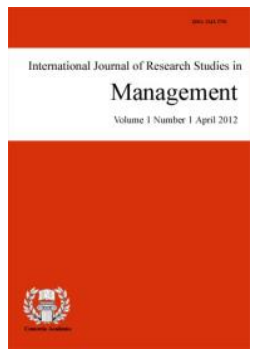

ISSN: $2243-7770$ Online ISSN: 2243-7789

OPEN ACCESS

\section{Abstract}

The study examines the adoption of digital marketing among farm tourism sites in Quezon, Province. This includes identifying the demographic profile of the respondents in terms of sex, age, occupation, civil status and Digital Platforms frequently used, determining the factors influencing the adoption of digital marketing in receiving farm tourism related advertisements in terms of Technology self-efficacy, Usefulness, Active Control, Two-Way Communication, and Synchronicity as well as determining the impact of digital marketing of farm tourism sites in Quezon, Province to customers' purchase intentions in the new normal in terms of performance expectancy, hedonic motivation, habit, interactivity, informativeness, and perceived relevance on respondents and lastly testing the significant difference on the assessment of the adoption of digital marketing when grouped according to the profile variables. The study used a survey questionnaire among 385 visitors of farm tourism sites as respondents. Based on the results, most of the respondents are 25 years old and below or Generation Z, male, in other occupation and majority are single. It was agreed by the respondents that usefulness was the most influential and synchronicity was the least. While, performance expectancy was agreed the most by the respondents on the impacts of digital marketing and the least was purchase intention. Significant difference was found on technology self-efficacy, usefulness, two-way communication and synchronicity among respondent working in the academe. As well as a significant difference in active control, two-way communication and synchronicity according to civil status. It was shown that the respondents agreed the most is the usefulness of digital marketing while the factor they agreed the least was synchronicity Also, the respondents agreed the most was performance expectancy and the factor that the respondents least agreed on was purchase intention. The study has a practical implication as it proposed a marketing innovative plan for the continuous improvement of the farm tourism.

Keywords: digital marketing, farm tourism, Quezon province, social media platforms 


\section{Adoption of digital marketing among farm tourism sites in the province of Quezon, Philippines}

\section{Introduction}

Digital marketing provides a great opportunity for farm tourism sites to advertise their establishments as well as their rural community. Through the use of digital marketing, it can reach audiences online that creates curiosity to visit the area because it is not common from their place of origin. Furthermore, digital marketing is a form of marketing that is commonly used nowadays to promote products and services, as well as reach consumers through digital channels such as the internet, social media platforms, mobile applications and other technologies about digital communications. Yasmin et al. (2015) stated that digital marketing refers to marketers using electronic media to promote products and services to the consumers. Also, digital marketing's main objective is to attract customers and allowing them to interact with the companies through digital media. The usage of social media has become an important part of the lives of people all over the world. It allows companies to reach their marketing goals in a moderately low cost with the use of digital and social media marketing (Dwivedi et al., 2021).

The pandemic brought a lot of changes specially to the tourism industry. People stay indoors due to the current situation brought by the pandemic and people only go out for necessities. According to the recent study of Yeh (2021) the COVID-19 outbreak leads to some disputes among different countries. Which have a great impact on the tourism sector about safety and regulations. Furthermore, there's an increase of screen time among the general populace due to Covid. Companies began to pivot to a digital marketplace in order to survive. The introduction of digital technologies and its advancement has influenced the environment where companies operate. The adoption of hand-held devices and technological innovation have contributed to the change of customer behavior in terms of how they interact and decision making Dwivedi et al. (2021). A new approach is required in marketing's new normal post pandemic. Sophisticated customers were created by social media platforms that gave way to the development of new processes on searching information, selecting, purchasing and evaluating products and services (Ratnasingam et al., 2021).

The Department of Tourism along with the Food and Agriculture Organization (FAO) teams up in promoting farm tourism and helping the country's tourism industry recover from the effects of Covid-19 pandemic. The Food and Agriculture Organization is a United Nations agency that leads the efforts to achieve food security and fight global malnutrition and hunger. The partnership will launch a program that makes farm tourism in selected areas of the Philippines sustainable and adaptable according to DOT (2020). Agritourism is a system in the form of agricultural that combines the elements of tourism and farming to create a niche for farm products and services that provide travel experience. Other terms of agritourism are farm tourism, farm-based tourism, farm stays, vacation farms, rural tourism and agritourism (Choenkwan et al., 2016).

Quezon Province is in the CALABARZON Region with combined land area of 870,660 hectares. It considered as the largest land area in the region and sixth in the country. Some famous tourist destinations in the province are the Balesin Island in Palilio, Quezon, Villa Escudero in Tiaong, Kamay ni Hesus in Lucban and Mount Banahaw. Aside from the famous tourist destinations in Quezon, there are emerging new tourist destinations in the different municipalities which are farm tourism. According to the provincial tourism office of Quezon, there are seven (7) recognized farm tourism sites in Quezon Province namely, Samkara Restaurant and Garden Resort, Batis Aramin Resort and Hotel, Villa Elma and Linang ni LK located in the municipality of Lucban. Cortijo De Palsabangon in Pagbilao. Oyayi Farm and Resort in Sariaya and Yumi's Farm located in Tayabas City.

Prior to increasing research and literature discussing digital marketing, the study focuses on the adoption of 
digital marketing in the new normal. Therefore, with the increasing trend on digital marketing and the emerging popularity of farm tourism in Quezon, Province. The researcher analyzed the adoption of digital marketing of the farm tourism sites in Quezon, Province. Whether the existing digital marketing practices of the farm tourism sites were effective based on the current situation. As well as understand what the current perception of the respondents toward digital marketing and its effectiveness were. This study serves as a reference to further improve the tourism marketing of the farm tourism sites and other tourist destinations and the identify social media platforms' effectiveness of as a marketing tool. The researcher believes that conducting this study will provide the possible recommendation with the use of digital marketing in promoting the farm tourism sites in Quezon, Province. As well as there is no prior research conducted regarding digital marketing of farm tourism sites in Quezon, Province.

\subsection{Objective of the Study}

The purpose of the study was to analyze digital marketing in the new normal of farm tourism sites in Quezon. Specifically, it sought to; identify the demographic profile of the respondents in terms of sex, age, occupation, and civil status; to determine the factors influencing the adoption of digital marketing in receiving farm tourism-related advertisements in terms of Technology self-efficacy (TSE), Usefulness (U), Active Control (AC), Two-Way Communication (TC), and Synchronicity (SY); to determine the impact of digital marketing of farm tourism sites in Quezon, Province to customers' purchase intentions in the new normal in terms of performance expectancy, hedonic motivation, habit, interactivity, informativeness, and perceived relevance on respondents; to test the significant difference on the assessment of the adoption of digital marketing when grouped according to the profile variables, and proposed Marketing Innovative plan relevant to creative value of digital marketing of the farm tourism sites in Quezon, Province.

\section{Methodology}

\subsection{Research Design}

The study used a descriptive method as a research design to analyze digital marketing in the new normal of farm tourism sites in Quezon. The descriptive method was an appropriate choice for the study because the research aims to analyze the factors influencing the adoption of digital marketing and its impacts in the new normal of farm tourism sites in Quezon.

\subsection{Participant of the Study}

The respondents of the study were the visitors of farm tourism sites of Quezon. A total of 385 samples were used based on the total population of one million one hundred seventeen thousand five hundred sixty-three $(1,117,563)$ of the 2020 general tourist arrivals from the Provincial Tourism Office of Quezon. The Rao soft sample size calculator was used to determine the sample size of the study. With the margin of error amounting to $5 \%$ and the confidence level of $95 \%$, the recommended sample size of the study is three hundred eighty-five (385). Stratified random sampling was used in the study. Whereas the sample size was divided into seven to come up with the equal number for each farm tourism site which is fifty-five (55). The researcher gathered the data based on the availability of the target respondents as well as their willingness to provide the required information.

\subsection{Data Collection Instrument}

The researcher adapted an instrument. Part one of the instrument is to present the profile of the respondents. Part two of the instrument is to determine the Factors influencing the adoption of digital marketing in receiving hotel-related advertisements that is based on the modified questionnaire from the study of Tan, et al., (2018) while part three of the instrument is an adapted questionnaire from the study of Alalwan (2018) which determine 
Orias, M. J. S., \& Borbon, N. M. D.

the Impact of Digital Marketing of farm tourism sites in Quezon, Province to Customers' Purchase Intentions in the New Normal. The instrument undergone into a content validation and pilot testing. The instrument's reliability was checked using the Cronbach Alpha Reliability Coefficient Test. Most of the variable in the study have an excellent value of Cronbach's alpha higher than 0.90 . The questions will be answered by a Likert 5-point scale. The scale is composed of numbers 1-5 where 5 is considered the highest and 1 as the lowest, where 5 is Strongly Agree, 4 is Agree, 3 is Moderately Agree, 2 is Disagree and 1 is Strongly Disagree.

\subsection{Data Gathering Procedure}

The researcher gathered the data based on the availability of the target respondents as well as their willingness to provide the required information. After the approval of the research instrument, the researcher provided a letter of permission signed by the researcher, and noted by the research adviser of the Graduate School of Lyceum of the Philippines University - Batangas that were addressed to the owners of the farm tourism sites to undertake the study in their establishments. Immediately after the request has been approved, the researcher administered the distribution of the questionnaire with the use of google form, in a stratified random sampling of visitors of the farm tourism sites. In addition, a letter addressed to the respondents directly attached to the questionnaire along with the data privacy agreement. The letter was a request for the participation in the research by completing the instrument. A qualifier question has been added to for the researcher to know if the respondent had visited any of the farm tourism sites listed on the study. The data was collected using the researcher's phone and some staff of the farm tourism sites. For the elderly respondents, the researcher read the questions to them, and the respondent will respond and the researcher input their answer on the form. The researcher retrieved the phone after the respondents completed answering the instrument.

\subsection{Data Analysis}

The data gathered was tallied and counted for frequency analysis. Each response to every question was shown in different tables and put into percentages. To perform data analysis, the following statistical tools were used. Frequency and percentage distribution were used to present the demographic profile of the respondents. Weighted means and ranking were used to determine the level of how respondents were influenced by factors influencing the adoption of digital marketing in receiving farm tourism-related advertisements and impact of digital marketing. Analysis of Variance (ANOVA) were used to test the significant difference as part of the non-parametric tests to determine the significant differences. Likewise, Spearman rho was used to test the significant relationship between the two variables. In addition, all data was treated using a statistical software known as PASW version 26 to further interpret the result of the study using an alpha level of 0.05 .

\subsection{Ethical Consideration}

The questionnaire was conducted online, and in accordance with the Code of Ethics, the researcher ensured that all the respondents answer the questions freely and voluntarily through a consent form, which guarantees that the respondents express their ideas and opinions according to their inner will. Further, there is no personal opinion to be utilized to avoid biases and ensure the validity of all the data.

\section{Results and Discussion}

\section{Table 1}

Percentage Distribution of the Respondents Profile

\begin{tabular}{|c|c|c|c|}
\hline Profile Variables & Items & Frequency & $(\%)$ \\
\hline \multirow{2}{*}{ Sex } & Male & 201 & 52.2 \\
\hline & Female & 184 & 47.8 \\
\hline
\end{tabular}


Table 1 ...continued

\begin{tabular}{lccc}
\hline & 25 years and below (Gen Z) & 152 & 39.5 \\
Age & $26-41$ years old (Gen Y) & 138 & 35.8 \\
& $42-56$ years old (Gen X) & 74 & 19.2 \\
& 57 years old and above (Baby Boomers) & 21 & 5.5 \\
& Academe & 44 & 11.4 \\
Occupation & Health and Medicine & 27 & 7 \\
& Public Officer & 30 & 7.8 \\
& Engineering and Architect & 29 & 7.5 \\
Civil Status & Police/Military Service & 35 & 9.1 \\
& Hospitality Industry & 68 & 17.7 \\
& Others & 152 & 39.5 \\
& Single & 255 & 66.2 \\
\hline
\end{tabular}

The table shows the summary of the percentage distribution of the respondents' profile. In which in terms of sex, male got the highest frequency and the percentage of 52.20 percent. Farm tourism can be interchange into the term agritourism which is a combination of tourism and agriculture. In addition, farm tourism sites are also working agricultural farms which visitors can gain knowledge about agriculture. To which, male individuals are more dominant in the agriculture setting compared to females. That is the reason why male respondents outnumbered the female respondents in the study. Based on the study of van Zyl and van der Merwe (2021) agri-tourism involves tourists visiting working farms for leisure and learning as well as the combination of tourism and agriculture industries. Since it is part of the agriculture industry, most visitors were male because agriculture is mainly a male dominated industry. Moreover, majority of developing countries are male dominated in population according to Bhatta and Ohe (2020). This is in contrast with the study of Abad and Borbon (2021) stating that Female loves to travel it is natural for them to go out and seek for fresh new adventure and just hang out with friends as compared to men, they tend to use their free time to just stay at home watch movie or just rest.

In terms of age, the respondents ages from 25 years and below or Gen $\mathrm{Z}$ got the highest percentage of 39.50. Based on the result, most of the respondents are generation $\mathrm{Z}$ or ages 25 years and below, it is because some of the older generation of Gen $\mathrm{Z}$ have more time to go in different place and legal to go out during the pandemic. While the other age groups are already adults and busy in the work force. That is why the Gen $\mathrm{Z}$ got the highest percentage. According to European Travel Commission (2020) Bloomberg predicted that Gen Z will overtake Millennials as the most populous generation on the planet in 2018. Which cause a change in consumer demand as the youngest generation grow older and starts to travel. According to Kelly (2020) Generation Z are starting to enter the workforce and some are still influencing their families travel plans. In relation to travel, almost $56 \%$ of Gen Zers preffer to experience adventure travelling as well as favoring the trend of independent excursions and small groups. Furthermore, Gen Zers are more concerned with social and environmental impact when they visit tourist destinations.

In terms of occupation, others got the highest percentage of 39.50. Based on the results, it got the highest because there is occupation that where not indicated among the choices. That is why most of the respondents selected the other occupation option. Yamagishi et al. (2020) stated that in attracting tourists and visitors to farm destinations for recreational, production and education purposes. Farmers and fisher men have more interests in visiting the farm sites who wanted to be educated and trained in related activities in agriculture. Furthermore, it provides education in relation to the importance and role of agriculture as well as creates a mutual learning experience which farmers share role in the community.

In terms of civil status, singles got the highest percentage of 66.20. Based on the results, majority of the respondents were single. It is because single individual may have more time to have leisure for themselves and have a less priority of parenthood. As well as, they have more authority in travel decision making compared to married individuals that requires feedback from the spouse and other family members. That is why more respondents were single. Kara and Mkwizu (2020) assumed that singles are have more free time to engage in 
Orias, M. J. S., \& Borbon, N. M. D.

different activities as compared with persons with a family. Furthermore, they have a higher chance of travel motivation such as discovering nature compared to married individuals. Biernat and Lubowiecki-Vikuk (2012) stated that singles prefer frequent but short trips. In addition, they have more time enjoying different activities compared to married couples.

\section{Table 2}

Factors influencing the adoption of digital marketing in receiving farm tourism-related advertisements

\begin{tabular}{lcccc}
\hline \multicolumn{1}{c}{ Indicators } & Cronbach Alpha & Weighted Mean & Verbal Interpretation & Rank \\
\hline 1. Technology self-efficacy & 0.853 & 4.07 & Agree & 2 \\
2. Usefulness & 0.958 & 4.11 & Agree & 1 \\
3. Active Control & 0.894 & 4.00 & Agree & 4 \\
4. Two-Way Communication & 0.914 & 4.05 & Agree & 3 \\
5. Synchronicity & 0.882 & 3.99 & Agree & 5 \\
\hline Composite Mean & 4.04 & 4.04 & Agree & \\
\hline Legend: $4.50-5.00=$ Strongly Agree; $3.50-4.49=$ Agree; $2.50-3.49=$ Moderately Agree; $1.50-2.49=$ Disagree; $1.00-1.49=$ Strongly \\
Disagree
\end{tabular}

The table 2 presents the assessment on the factors influencing the adoption of digital marketing in receiving farm tourism-related advertisements where the composite mean is the 4.04 with the verbal interpretation of agree. Usefulness got the highest mean score of 4.11, followed by technology self-efficacy where its mean score is 4.07 and agree was its verbal interpretation. Third is the two-way communication and its mean score is 4.05 and verbal interpretation of agree.

Among the variables in the table, usefulness got the highest mean score. The respondents use the digital sites for multiple reasons specially during this digital age. People nowadays use digital platforms every day for certain reasons such as communication, information, and entertainment. Viewers tend to rely on information they see on social media platforms to support their decision-making process based on the posts of their friends and relatives. Social media platforms have an important role in the tourism industry, specifically in searching information and decision-making behaviors of tourists, as well as tourism promotion and best practices on interacting with consumers (Zeng \& Gerritsen, 2014). According to Tahar et al. (2020), usefulness describes the degree to which users feel that with the use of technology, they can improve their performance. Where this is part of the technology acceptance model (TAM) describes the users' perception on technology. It also explains the system characteristics' effects of computer-based technology systems on users (Tahar et al., 2020).

However, active control got the second lowest of mean of 4.00 and verbal interpretation of agree. The lowest among the variables is the synchronicity where it got the mean of 3.99 and its verbal interpretation of agree. Based on the results, the respondents find synchronicity the least among the variables because they may not be satisfied on the contents being posted on the digital platforms of the farm tourism sites, such as outdated basic information and digital content. As well as not being consistent on posting any content on their digital platforms which is found by the respondents important in their decision-making process to visit the farm tourism sites. Duggan and Lang (2010) stated that user's information and travel details were provided by tourism websites that can be an important tool for their trip. The high number of available content and reliable information that can be found on the website may produce a high user satisfaction. Customer satisfaction in travel websites is influenced by the system, quality of service and information. Hence, information quality, informativeness and security determined a significant qualifications of customer satisfaction (Milojica, 2019).

The table 3 represents the summary of the impact of digital marketing with a composite mean of 4.05 and agree as its verbal interpretation. Among the variables cited, performance expectancy got the highest mean score of 4.13 and the verbal interpretation of agree. Followed by informativeness with the mean score of 4.07. Then hedonic motivation, perceived relevance and interactivity got the same mean score of 4.06. All items got agree as the verbal interpretation. 
Table 3

Impact of Digital Marketing

\begin{tabular}{lcccc}
\hline \multicolumn{1}{c}{ Indicators } & Cronbach Alpha & Weighted Mean & Verbal Interpretation & Rank \\
\hline 1.Performance Expectancy & 0.935 & 4.13 & Agree & 1 \\
2. Hedonic Motivation & 0.886 & 4.06 & Agree & 4 \\
3. Perceived Relevance & 0.973 & 4.06 & Agree & 4 \\
4. Habit & 0.961 & 4.01 & Agree & 6 \\
5. Interactivity & 0.940 & 4.06 & Agree & 4 \\
6. Informativeness & 0.939 & 4.07 & Agree & 2 \\
7. Purchase Intention & 0.961 & 3.97 & Agree & 7 \\
\hline Composite Mean & 4.05 & 4.05 & Agree & \\
\hline Legend: $4.50-5.00=$ Strongly Agree; $3.50-4.49=$ Agree; $2.50-3.49=$ Moderately Agree; $1.50-2.49=$ Disagree; $1.00-1.49=$ Strongly \\
Disagree
\end{tabular}

People nowadays relay on technology for multiple reasons, to make their day-to-day activities easier and convenient for them. Similar with digital marketing, the respondents tend to relay on digital platforms for information, communication etc. The effect of the digital advertisements encourages the viewers to visit the farm tourism sites based on the information they gathered from multiple sources online such as online posts from their friends and relatives, personal vlogs on famous influencers, product reviews and more, which solidify their decision. That is why the respondent refer to it as the highest among the variables given. According to Abdat (2020) that performance expectancy refers to as the degree in which users believe that using a new technology or system will help them accomplish tasks better. Furthermore, it was found that performance expectancy along with social influence and effort expectancy are significant predictors of users' behavior intention in using web-based services. In addition, Igudia and Ogunsina (2021) stated that performance expectancy had a positive correlation with social media use in marketing. In addition, they stated that performance expectancy had a positive correlation with social media use in marketing. Also, it is one of the factors the affects the adoption of information technology and considered the behavioral intention's strongest predictor is to use m-learning according to (Nawi et al., 2016).

However, habit got second to the lowest mean of 4.01 and purchase intention got the lowest among the variables with the mean score of 3.97. Both items got the verbal interpretation of agree. Purchase intention of the respondents may be influenced by different factors, such as essential goods and different priorities, or change of mind due to some information that may influenced their decision. As the tourism industry is starting to open again, people are starting to travel again. However, people are still very cautious and need to put their priorities first before taking leisure activities. That is why people are still hesitant in their purchase intention caused by the pandemic. Laksamana (2016) stated that purchase intention refers to the possibility of customers to purchase products and services soon. Customers have constant buying decisions and numerous options in the market, and they have to deal with an excessive amount of information. According to Koch et al. (2020) the determinant of purchase intention in reference to e-commerce associates with the importance of utilitarian and hedonic motives. Utilitarian motives refer to the usefulness behavior and hedonic motives refers to the behavior of enjoyment and entertainment. Furthermore, during the crisis, it was revealed that information from the situation of the current economy available in the media as well as pressure from social network influence the customers' purchase behavior.

Table 4 illustrates the comparison of responses on the factors influencing the adoption of digital marketing in receiving farm tourism-related advertisements when grouped according to profile. It was observed that there was significant difference when grouped according to sex and digital platform used since the obtained p-values were less than the prescribed alpha level of 0.05. This means that the responses vary significantly and based on the post hoc test conducted, females and those who always used the digital platform have greater assessment on the factors influencing the adoption of digital marketing in receiving farm tourism-related advertisements. This result reveals that female tend to view digital marketing significantly towards factors such as Technology self-efficacy, Usefulness, Active Control, Two-Way Communication and Synchronicity. In addition, in terms of agreeing to the statement on the advertisement viewed by a customer; it shows that female respondents have a 
Orias, M. J. S., \& Borbon, N. M. D.

tend to agree more with the male. Yamagashi, et al. (2020) stated in agritourism, females are considered more interested to engage in the farm tourism activities than males. Also, females tend to engage initiative due to the diversification of agritourism (Bhatta \& Ohe, 2020).

\section{Table 4}

Difference factors influencing the adoption of digital marketing in farm tourism-related advertisements

\begin{tabular}{llll}
\hline Sex & $\mathrm{U} / \lambda 2 \mathrm{c}$ & $\mathrm{p}$-value & Interpretation \\
\hline Technology self-efficacy & 35.031 & 0.000 & Highly Significant \\
Usefulness & 25.557 & 0.000 & Highly Significant \\
Active Control & 17.098 & 0.001 & Highly Significant \\
Two-Way Communication & 21.16 & 0.000 & Highly Significant \\
Synchronicity & 23.042 & 0.000 & Highly Significant \\
\hline Age & & & \\
\hline Technology self-efficacy & 17614.5 & 0.417 & Not Significant \\
Usefulness & 16300.5 & 0.042 & Significant \\
Active Control & 17317.5 & 0.275 & Not Significant \\
Two-Way Communication & 16682 & 0.093 & Not Significant \\
Synchronicity & 17984 & 0.637 & Not Significant \\
\hline Occupation & & & \\
\hline Technology self-efficacy & 14.168 & 0.028 & Significant \\
Usefulness & 16.419 & 0.012 & Significant \\
Active Control & 11.629 & 0.071 & Not Significant \\
Two-Way Communication & 18.526 & 0.005 & Significant \\
Synchronicity & 15.797 & 0.015 & Significant \\
\hline Civil Status & & & \\
\hline Technology self-efficacy & 454.5 & 0.094 & Not Significant \\
Usefulness & 470 & 0.138 & Not Significant \\
Active Control & 420 & 0.037 & Significant \\
Two-Way Communication & 362 & 0.005 & Significant \\
Synchronicity & 381 & 0.010 & Significant \\
\hline Lege Sigificat & & &
\end{tabular}

Legend: Significant at p-value $<0.05$

As to age, the responses vary on usefulness $(p=0.042)$ because the resulted p-value was less than the alpha level. This means that the respondents assessment varies, and this was found out on those who are 25 years old and below. In terms of usefulness, the respondents ages 25 years old and below or the Generation $\mathrm{Z}$ tend to have a greater assessment on the usefulness of digital marketing. In terms of social media, majority of Gen $\mathrm{Z}$ prefers to use Instagram and YouTube because of their appetite for short-form video contents. Furthermore, Gen Zs are considered digital natives that are baffling the marketing world to develop effective strategies for digital advertising in order to influence consumer behavior, since their generation is a larger number of populations compared to the millennials. Also, most of the millennials are already in the workforce. Digital native refers to regularly interacting with technology at a young age and they are accustomed into using technology in solving repetitive tasks which is a form of basis of traditional learning and engagement in society according to (Munsch, 2021).

There was also significant difference on technology self-efficacy $(p=0.028)$, usefulness $(p=0.012)$, two way communication $(p=0.005)$ and synchronicity $(p=0.015)$ when grouped according to occupation. Significant difference was observed with those who are in the academe. Technology self-efficacy is an indicator that is useful for teacher's education program to see the effectiveness in preparing graduates in using instructional technology, where the teacher's technology self-efficacy is credited for their graduates' use of instructional technology throughout their careers. Furthermore, it is essential for positive teacher-efficacy for an effective instructional technology integration. It also affects behavioral preferences to use technological tools and perception of the usefulness of technology for learning. Kent and Giles (2017) stated that experienced teachers' efficacy is difficult to change. In addition, the technological self-efficacy has a positive influence to people in the academe on technology acceptance and utilization of individual's control beliefs in technology use Pan (2020).

Lastly, there was a significant difference on active control $(p=0.005)$, two-way communication $(p=0.010)$ and synchronicity $(p=0.010)$ when grouped according to civil status. Based on the pairwise comparison, it was 
found out that those who are single have greater assessment on active control, communication, and synchronicity. Based on the results, single respondents have greater assessment on active control, communication, and synchronicity because they have more time to focus on themselves and have other priorities compared to married individuals that have other priorities and distractions such as parenthood. According to Lennon, et al. (2015), singles are more likely to view social networks as easy to use, considered as useful and enjoyable compared to individuals in a relationship. Based on the demographic profile in the study of Hruska and Maresova (2020) the group that uses social media the most were under the category were never married.

\section{Table 5}

Proposed Marketing Innovative Plan for Farm Tourism

\begin{tabular}{|c|c|c|}
\hline Key Result Area & Strategies & Desired Outcome \\
\hline $\begin{array}{l}\text { Synchronicity } \\
\text { To create a systemized production of } \\
\text { digital content throughout different } \\
\text { digital platforms according to the } \\
\text { current trends and situation of the } \\
\text { farm tourism sites }\end{array}$ & $\begin{array}{l}\text { Creating a digital content time schedule such as: } \\
\text { - Weekly updates about the farm tourism site } \\
\text { - Weekly trivia about the site and farm tourism in } \\
\text { general } \\
\text { - Collaboration with government organizations or } \\
\text { local businesses such as DOA, TESDA, event } \\
\text { coordinators and the like }\end{array}$ & $\begin{array}{l}\text { Tourist will be able to see different, } \\
\text { up to date and relevant contents } \\
\text { which may encourage them to visit } \\
\text { the farm tourism sites. As well as } \\
\text { positive reviews among the quality } \\
\text { of content being posted. }\end{array}$ \\
\hline $\begin{array}{l}\text { Active Control (AC) } \\
\text { To improve the usage of the digital } \\
\text { platforms being used by the farm } \\
\text { tourism sites }\end{array}$ & $\begin{array}{l}\text { Creating content that will make the viewers participate or } \\
\text { interact with the farm tourism sites such as: } \\
\text { - Creating virtual competitions like photography that } \\
\text { will make the viewers express their insights and } \\
\text { opinions as well as offering interesting prizes } \\
\text { - Continuous update of information online in order to } \\
\text { optimize the search engine features such as } \\
\text { google searches, in order for the farm tourism } \\
\text { site to be on the top results when searched on } \\
\text { specific keywords }\end{array}$ & $\begin{array}{l}\text { Tourists will be interested to } \\
\text { participate that they may share on } \\
\text { their social media accounts. }\end{array}$ \\
\hline $\begin{array}{l}\text { Technology self-efficacy (TSE) } \\
\text { To create informative and } \\
\text { instructional content to improve } \\
\text { technology self-efficacy of users }\end{array}$ & $\begin{array}{l}\text { Creating informative and instructional content to improve } \\
\text { confidence and usage of the farm tourism sites' digital } \\
\text { platforms such as: } \\
\text { - Online reservation instructions for user to easy } \\
\text { understand the process } \\
\text { - Posting of latest communication options for users to } \\
\text { easily communicate with the farm tourism sites } \\
\text { - Creation of things to do content using digital devices } \\
\text { while in the farm tourism sites }\end{array}$ & $\begin{array}{l}\text { Tourists will increase their } \\
\text { confidence as they see contents that } \\
\text { will help them to get more } \\
\text { comfortable using the digital } \\
\text { platforms. }\end{array}$ \\
\hline $\begin{array}{l}\text { Two-way communication (TC) } \\
\text { To improve two-way communication } \\
\text { (TC) between farm tourism sites and } \\
\text { new and existing guests }\end{array}$ & $\begin{array}{l}\text { Improvement of customer relations between the farm } \\
\text { tourism sites and the tourists in terms: } \\
\text { - responsiveness through online messages, emails, } \\
\text { comments and reviews } \\
\text { - creation of guidelines on how long the management } \\
\text { should respond to every inquiry } \\
\text { - creation of standard response to frequently asked } \\
\text { questions in order to have a generic but concise } \\
\text { response to every tourist. }\end{array}$ & $\begin{array}{l}\text { Tourists will be comfortable } \\
\text { communication with the farm } \\
\text { tourism sites and will gain their } \\
\text { trusts due to their responsiveness to } \\
\text { the tourist's inquiry as well as } \\
\text { shows professionalism from the } \\
\text { establishment. }\end{array}$ \\
\hline
\end{tabular}

\section{Conclusion and Recommendation}

Majority of the respondents were male and single. Most of the respondents are ages 25 and below and have other occupations aside the list given. In terms of digital platforms frequently visited by the respondents. Lastly, the digital platforms that most respondents never visited are Twitter, LinkedIn and Travel Booking Websites. In terms of the factors influencing the adoption of digital marketing in receiving farm tourism-related advertisements, respondents agreed the most is the usefulness of digital marketing in promoting the farm tourism sites in Quezon to existing and potential tourists, while the factor they agreed the least was synchronicity of digital marketing in relation to promoting farm tourism sites. In terms of the impact of digital marketing, the respondents agreed the most is on performance and the factor that the respondents least agreed on is purchase intention, to which the respondents felt that the digital marketing of the farm tourism sites didn't had much impact regarding to their purchase intention on visiting farm tourism sites. About the significant difference on the factors influencing the adoption of digital marketing when group according to respondents' profile are as 
follows. It was found that females who have always used digital marketing have greater assessment on the factors influencing the adoption of digital marketing in receiving farm-related advertisements. In terms of age, ages 25 years old and below or the Generation $\mathrm{Z}$ have greater assessment of the usefulness of digital marketing. There was a significant difference on technology self-efficacy, usefulness, two way-communication and synchronicity observed on those who are in the academe in terms of occupation. Lastly, singles have greater assessment on active control, communication, and synchronicity. Significant differences were found in terms of active control, two-way communication and synchronicity when grouped according to civil status. A sample Digital Marketing Innovative Plan was proposed in order to help the farm tourism sites identify their own style and brand to market digitally as well as improve their operation through digital marketing.

From the conclusion, the following statements are recommended: Farm tourism sites may encourage female visitors to engage more on farm tourism to increase the involvement of female to farming and agriculture and improve the digital marketing to attract married visitors ages 42 to 56 years old as well as ages 57 and above, it could be a good place for relaxation away from the city. The improvement would also attract visitors from other occupational sectors such as health and medicine, engineering and architect and public office, to broaden the reach from different occupational sectors. Other farm activities may be applied to attract visitors, with the collaboration of LGUs to identify the needs of other visitors. Such collaboration between farm tourism sites in Quezon and LGU along with the support of the provincial and national government offices specifically in tourism and agriculture which may create programs that encourage individuals to have interests in farming and agriculture.

Farm tourism sites may improve the active control and synchronicity of their digital marketing to attract new visitors, since it would be the first impression of the farm tourism site to potential visitors. It could be done by regularly updating the farm tourism sites' digital platforms to spread up to date information by the management of the farm tourism sites. Furthermore, the use of frequent surveys from their visitors to know the current trends of travelers, as well as providing the information and content that may caught the viewers' attention on the farm tourism sites, providing information to the local tourism offices to further market the farm tourism sites may also be applied.

The impact of digital marketing to the respondents such as habit and purchase intention may be improved. The management of the farm tourism sites may seek collaboration or partnership with other individual or organization for the improvement. In terms of uploading content in collaboration with different sectors, the local government or private individuals may catch the attention of viewers online causing curiosity for visit the farm tourism sites. Promoting the farm tourism sites as event venues, sponsorship of products or product placements, as well as producing content that uses locally produced farm products that are being integrated in the day-to-day activities of people to provide awareness of the products in the farm may be considered. This recommendation can be facilitated by both organizations since it can be beneficial for both parties.

The significant difference of the identified factors should be improved to increase the assessment of each identified variable. Improvement of the usefulness of digital platforms to older age groups by providing easy to understand the contents being posted, as well as, providing digital content to encourage male individuals to visit the digital platforms of the farm tourism sites may be done. Furthermore, continuing to improve the production and managing of the contents being posted online since most of the digital platforms are significant to the adoption of digital marketing of the farm tourism sites in Quezon may be undertaken.

A marketing innovative plan specifically on creative value of digital marketing of the farm tourism sites is proposed to improve the farm tourism sites' digital marketing and increase the tourists flow and revenue, not only as a tourism site as well as improve the agricultural products and promote local produce to the market. With the help of the farm tourism establishment, LGU and provincial tourism office in proper implementation and other related support needed, the plan can be proposed to the LGU and the provincial office to gain better support and provide a better insight in how it can be properly implemented based on the current procedures and 
laws being implemented.

For future research, an evaluation of the proposed marketing innovative plan and its effectiveness on the current business situation may serve as a new topic of research. Future researchers may adapt this research and may continue to widen the scope of the research study by including the whole region as the research locale.

\section{References}

Abad, P. E. S., \& Borbon, N. M. D. (2021). Influence of travel vlog: Inputs for destination marketing model. International Journal of Research Studies in Management, 9(3), 47-66. https://doi.org/10.5861/ijrsm.2021.m7729

Abdat, F. A. (2020). Using UTAUT Model to Predict Social Media Adoption among Indonesian SMEs. Saudi Journal of Economics and Finance, 4(10), 498-505. https://doi.org/10.36348/sjef.2020.v04i10.003

Bhatta, K., \& Ohe, Y. (2020). A Review of Quantitative Studies in Agritourism: The Implications for Developing Countries. Tourism and Hospitality, 1(1), 23-40. https://doi.org/10.3390/tourhosp1010003

Choenkwan, S., Promkhambut, A., Hayao, F., \& Rambo, A. T. (2016). Does Agrotourism Benefit Mountain Farmers? A Case Study in Phu Ruea District, Northeast Thailand. Mountain Research and Development, 36(2), 162-172. https://doi.org/10.1659/mrd-journal-d-15-00111.1

DOT, FAO team up for sustainable farm tourism in PH. (2020). Department of Tourism. Retrieved August 3, 2021, from http://www.tourism.gov.ph/news features/dotfaoteamupforsustainablefarmtourisminph.aspx

Duggan, K. J., \& Lang, J. (2010). Six drivers for high-user satisfaction of tourism websites: Performance auditing of Maine, Massachusetts, and New York's direct marketing strategies. Tourism-Marketing Performance Metrics and Usefulness Auditing of Destination Websites, 27-45. https://doi.org/10.1108/s1871-3173(2010)0000004007

Dwivedi, Y. K., Ismagilova, E., Hughes, D. L., Carlson, J., Filieri, R., Jacobson, J., Jain, V., Karjaluoto, H., Kefi, H., Krishen, A. S., Kumar, V., Rahman, M. M., Raman, R., Rauschnabel, P. A., Rowley, J., Salo, J., Tran, G. A., \& Wang, Y. (2021). Setting the future of digital and social media marketing research:

Perspectives and research propositions. International Journal of Information Management, 59, 102168. https://doi.org/10.1016/j.ijinfomgt.2020.102168

European Travel Commission \& European Travel Commission. (2020). Study on Generation Z Travellers. European Travel Commission (ETC).

Hruska, J., \& Maresova, P. (2020). Use of Social Media Platforms among Adults in the United States-Behavior on Social Media. Societies, 10(1), 27. https://doi.org/10.3390/soc10010027

Igudia, O., \& Ogunsina, S. (2021). Effort Expectancy and Use of social media for Marketing by Staff of Selected Publishing Firms in South-West, Nigeria. University of Nebraska - Lincoln. Published. https://digitalcommons.unl.edu/cgi/viewcontent.cgi?article=9084\&context=libphilprac

Kara, N. S., \& Mkwizu, K. H. (2020). Demographic factors and travel motivation among leisure tourists in Tanzania. International Hospitality Review, 34(1), 81-103. https://doi.org/10.1108/ihr-01-2020-0002

Kelly, H. (2021, July 19). The Importance of Gen Z to Travel's Recovery. AdventureTravelNews. https://www.adventuretravelnews.com/the-importance-of-gen-z-to-travels-recovery

Kent, A., \& Giles, R. (2017). Preservice Teachers' Technology Self-Efficacy. SRATE Journal, 26(1), 19-20. https://files.eric.ed.gov/fulltext/EJ1134392.pdf

Koch, J., Frommeyer, B., \& Schewe, G. (2020). Online Shopping Motives during the COVID-19 Pandemic — Lessons from the Crisis. Sustainability, 12(24), 10247. https://doi.org/10.3390/su122410247

Laksamana, P. (2016). The Influence of Consumer Ethnocentrism, Perceived Value and Brand Credibility on Purchase Intention: Evidence from Indonesia's Banking Industry. Journal of Marketing Management (JMM), 4(2). https://doi.org/10.15640/jmm.v4n2a8

Lennon, R., Rentfro, R., \& Curran, J. (2015). Exploring relationships between demographic variables and social networking use. Journal of Management and Marketing Research. 
Orias, M. J. S., \& Borbon, N. M. D.

https://www.aabri.com/manuscripts/121164.pdf

Milojica, V. (2019). Measuring users' satisfaction with tourism website contents and their intention of future recommendations. Turizam, 23(4), 86-99. https://doi.org/10.5937/turizam23-22206

Munsch, A. (2021). Millennial and generation $\mathrm{Z}$ digital marketing communication and advertising effectiveness: A qualitative exploration. Journal of Global Scholars of Marketing Science, 31(1), 10-29. https://doi.org/10.1080/21639159.2020.1808812

Nawi, N. B. C., Nasir, N. A. B. M., \& Al Mamun, A. (2016). Factors contributing to the acceptance of social media as a platform among student entrepreneurs: A review. Mediterranean Journal of Social Sciences, 7(2), 42. https://doi.org/10.5901/mjss.2016.v7n2p42

Pan, X. (2020). Technology acceptance, technological self-efficacy, and attitude toward technology-based self-directed learning: Learning motivation as a mediator. Frontiers in Psychology, 11. https://doi.org/10.3389/fpsyg.2020.564294

Ratnasingam, J., Jegathesan, N., Ab Latib, H., Ioras, F., Mariapan, M., \& Liat, L. C. (2021). Digital marketing during the COVID-19 pandemic: A case study of its adoption by furniture manufacturers in Malaysia. BioResources, 16(2), 3304-3317. https://doi.org/10.15376/biores.16.2.3304-3317

Tahar, A., Riyadh, H. A., Sofyani, H., \& Purnomo, W. E. (2020). Perceived Ease of Use, Perceived Usefulness, Perceived Security and Intention to Use E-Filing: The Role of Technology Readiness. The Journal of Asian Finance, Economics and Business, 7(9), 537-547. https://doi.org/10.13106/jafeb.2020.vol7.no9.537

Tan, G. W. H., Lee, V. H., Hew, J. J., Ooi, K. B., \& Wong, L. W. (2018). The interactive mobile social media advertising: An imminent approach to advertise tourism products and services? Telematics and Informatics, 35(8), 2270-2288. https://doi.org/10.1016/j.tele.2018.09.005

van Zyl, C. C., \& van der Merwe, P. (2021). The motives of South African farmers for offering agri-tourism. Open Agriculture, 6(1), 537-548. https://doi.org/10.1515/opag-2021-0036

Yamagishi, K., Gantalao, C., \& Ocampo, L. (2021). The future of farm tourism in the Philippines: challenges, strategies and insights. Journal of Tourism Futures, ahead-of(ahead-of-print). https://doi.org/10.1108/jtf-06-2020-0101

Yasmin, A., Tasneem, S., \& Fatema, K. (2015). Effectiveness of digital marketing in the challenging age: An empirical study. The International Journal of Management Science and Business Administration, 1(5), 69-80. https://doi.org/10.18775/ijmsba.1849-5664-5419.2014.15.1006

Yeh, S. S. (2020). Tourism recovery strategy against COVID-19 pandemic. Tourism Recreation Research, 46(2), 188-194. https://doi.org/10.1080/02508281.2020.1805933

Zeng, B., \& Gerritsen, R. (2014). What do we know about social media in tourism? A review. Tourism Management Perspectives, 10, 27-36. https://doi.org/10.1016/j.tmp.2014.01.001 